\title{
Leaf anatomy of Araucaria angustifolia (Bertol.) Kuntze (Araucariaceae)
}

\author{
ALEXANDRA A. MASTROBERTI ${ }^{1,2}$ and JORGE E.A. MARIATH ${ }^{1}$
}

(received: July 19, 2001; accepted: June 11, 2003)

\begin{abstract}
Leaf anatomy of Araucaria angustifolia (Bertol.) Kuntze (Araucariaceae)). Immature and mature leaves of juvenile and adult plants of Araucaria angustifolia (Araucariaceae) were observed with the objective of updating the morphoanatomical data of the leaves of this species, which were restricted to basic descriptions in previous studies. The observations, made in optical allowed to establish anatomical differences among mature leaves of juvenile and adult plants in relation to the number of palisade parenchimal layers, the number of compartmented cells and the transfusion tissue development. Epidermis, the albuminous cells, the phloem, and the transfusion tissue descriptions are in disagreement with the data obtained data by different authors. The epidermal tissue and the hypodermis differ entirely when the plant is still juvenile, being inferred that these tissues would soon perform the protection function against mechanical damages and water loss, the vital characteristics during the first development months of young offspring.
\end{abstract}

Key words - Araucaria angustifolia, Araucariaceae, leaf anatomy

RESUMO - (Anatomia foliar de Araucaria angustifolia (Bertol.) Kuntze (Araucariaceae)). Foram observadas folhas imaturas e maduras de plantas jovens e adultas de Araucaria angustifolia (Araucariaceae), com o objetivo de atualizar os dados morfoanatômicos das folhas desta espécie, cujos estudos anteriores se restringiam a descrições básicas. As observações efetuadas em microscopia óptica permitiram estabelecer diferenças anatômicas entre folhas maduras de plantas jovens e adultas, com relação ao número de camadas do parênquima paliçádico, número de células compartimentadas e desenvolvimento do tecido de transfusão. As descrições para a epiderme, células albuminosas, floema e tecido de transfusão, não estão de acordo com os dados obtidos por diferentes autores. $\mathrm{O}$ tecido epidérmico e hipoderme se diferenciam por completo quando a planta ainda é jovem, inferindo-se que estes tecidos desempenhariam logo a função de proteção contra danos mecânicos e perda de água, característas vitais durante os primeiros meses de estabelecimento da planta jovem.

Palavras-chave - anatomia foliar, Araucaria angustifolia, Araucariaceae

\section{Introduction}

The anatomical aspects of Araucariaceae family were already widely studied (Chamberlain 1935, NappZinn 1966, Vasiliyeva 1969, Burrows 1987), including both the vegetative and reproductive organs. Nowadays, the Araucariaceae is constituted by the genera Araucaria Juss., Agathis Salisb. and Wollemia W.G. Jones, K.D. Hill \& J.M. Allen, for which the adult plant anatomy has been described (Monteiro et al. 1977, Carr \& Carr 1977, Jones et al. 1995, Burrows \& Bullock 1999). Several authors have studied the leaf anatomy of the genus Araucaria (Seward \& Ford 1906, Barsali 1909, Thomson 1914, Vasiliyeva 1969, Monteiro et al. 1977), including cuticular aspects (Stockey \& Taylor 1978), the shoot apex that has been described as possessing a tunica-corpus organization (Griffith 1952) and anatomical aspects of the whole plant (Chamberlain

\footnotetext{
1. Universidade Federal do Rio Grande do Sul, Instituto de Biociências, Departamento de Botânica, Laboratório de Anatomia Vegetal. Av. Bento Gonçalves, 9500 Prédio 43423 sala 206, 91501-970 Porto Alegre, RS, Brazil.

2. Corresponding author: a_mastroberti@yahoo.com
}

1935, Napp-Zinn 1966). A great part of the leaf anatomical analysis has addressed the genus Araucaria, maybe due to the largest number of species within the family and its phylogenetic importance (Gilmore \& Hill 1997, Setoguchi et al. 1998, Stefanovic et al. 1998).

The species Araucaria angustifolia (Bertol.) Kuntze is native of Brazil, Argentina and Paraguay, largely occurring in the south of Brazil, in the states of Rio Grande do Sul, Santa Catarina and Paraná. Smaller concentrations are found in the states of São Paulo (Serra de Paranapiacaba, Campos do Jordão), Rio de Janeiro, Minas Gerais (Serra da Mantiqueira), and Espírito Santo (Pico da Bandeira). Additionally, it is one of the most important Brazilian native forest essences (Backes 1999).

The main studies of Araucaria angustifolia involved anatomical aspects of adult plants (Barsali 1909, Vasiliyeva 1969, Stockey \& Taylor 1978, Burrows 1987, Marchiori 1996), floristic composition (Reitz \& Klein 1966, Mattos 1994, Backes 1999), seed development (Ferreira 1977, Ferreira et al. 1979), reproductive biology (Shimoya 1962) and embryology (Burlingame 1913, 1914, 1915, Haines \& Prakash 1980). Unfortunately, there is no current information regarding 
anatomy of juvenile plants, since the literature brings only general descriptions of leaf anatomy (Monteiro et al. 1977), physiological aspects (Franco \& Ferreira 1987, Yamasaki \& Dillemburg 1999) or developmented studies (Gurgel Filho 1959, Ferreira, 1985).

Because of the lack of anatomical studies regarding the Araucaria angustifolia juvenile plants, and the imprecise and contradictory data found in the literature, the anatomy of the leaves of this species was examined with an emphasis on comparison of juvenile plants, between the age of two to four months, with adult ones.

The morphoanatomical characteristics of the immature and mature leaves of this species, adds a developmental dimension to this study, explanding the scope of the ontogeny, taxonomy and evolutionary aspects of this genus.

\section{Material and methods}

Collection - Seeds and leaves of adult plants were collected at the National Forest of São Francisco de Paula (Flona), Rio Grande do Sul, Brazil. The Flona is located between $29^{\circ} 23^{\prime}$ and $29^{\circ} 27^{\prime}$ of south latitude and $50^{\circ} 23^{\prime}$ ' and $50^{\circ} 25^{\prime}$ ' of west longitude, northeast of Rio Grande do Sul, in São Francisco de Paula district. The seeds were cultivated in a seed bed, and leaves were collected when the juvenile plants reached the age of two to four months ( 10 to $21 \mathrm{~cm}$ height).

Immature leaves - Four leaves (approximately, $1.5 \mathrm{~cm}$ in length) were collected from each shoot apex of five juvenile plants and one adult plant; being chosen just those ones between the $8^{\text {th }}$ and $10^{\text {th }}$ node.

Mature leaves - Four leaves (approximately 3 to $4.5 \mathrm{~cm}$ in length) were collected from the medium portion of the stem of each five juvenile plant, and from the adult plant's inferior branches. Optical microscopy - The material was fixed in glutaraldehyde $1 \%$ and paraformaldehyde $4 \%$, washed in phosphate buffer, pH 7.2 (Gabriel 1982) and dehydrated in ethanol graded series (Johansen 1940) and chloroform-absolute alcohol series 1:3; 1:1; 3:1 (Purvis et al. 1964). Later, the material was included in hydroxyethylmethacrylate (Jung-historesin) and sectioned in a Zeiss Microm HM340E microtome with a glass knife, in 2 $\mu \mathrm{m}$ thickness. The sections were stained with toluidine blue O (O’Brien \& McCully 1981) and analyzed in bright-field and polarized light (without staining), using a Leitz Dialux $20 \mathrm{~EB}$ and an Zeiss Jena Amplival polarization microscopes, respectively.

Histochemical tests - Manual sections of fresh material were accomplished, both in mature and immature leaves of juvenile plants. The sections were stained with Sudan III (Sass 1951) for lipid compounds (cutin, suberin); Schiff's reagent (PAS) (O’Brien \& McCully 1981) for total polysaccharides; Steimetz modified (Lima 1963) for phenolic compounds and lipids (universal reactive); phloroglucinol $+\mathrm{HCl} 20 \%$ (Sass 1951) for lignins of guaiacyl group; ruthenium red (Johansen 1940) for pectins; and lugol (Johansen 1940) for starch detection.

\section{Results}

Anatomy of mature leaves in juvenile plants - Based on the general histological aspects analysed, the mature leaves of juvenile plants have a well defined xeromorphical characteristics, considering the epidermis outer periclinal walls, the lignified hypodermis and the palisade parenchyma (figure 1).

The epidermis is unistratified, constituted of rectangular outline cells in transverse section, and stretched in paradermal and longitudinal section, with thicker outer periclinal walls (figures 2, 3).

The stomata, distributed in both leaf sides (amphistomatic), presents guard cells with very lignified periclinal walls, located at the same level of the other epidermal cells. In paradermal sections, it was observed four to six subsidiary cells enveloping the guard cells (figure 3).

The hypodermis is constituted by one or two layers of polygonal cells, in transverse section, with thickened walls impregnated by lignin and with narrow lumen. The hypodermis layer, which is contiguous to the epidermis, is continuous, while the second layer, the one which is in contact with the palisade parenchyma, does not present this characteristic, being usually discontinuous (figures 1,2). In the leaf margin, this tissue can develop up to three cell layers (figure 4). In paradermal and longitudinal sections, this cells are more stretched out than that ones of the epidermis (not shown).

The palisade parenchyma is stratified and contains phenolic compounds and many chloroplasts, being more developed in the adaxial side than in the abaxial one (figure 1). The spongy parenchyma occupies about $90 \%$ of the mesophyll, also with many chloroplasts. It is constituted by polygonal cells in transverse section (figure 1).

Among the cells of the spongy parenchyma, are compartmented cells (figures 1,5 ). These cells have a great amount of pectic material in their lumen, forming sometimes a net-like pectic secretion. They are cells of larger dimensions and high number, comparing to the other cells of the spongy parenchyma, forming cords when observed in paradermal and longitudinal sections. They are distributed in a more abundant way in the abaxial leaf side, being in contact with the resin canals, with the endodermis and, sometimes, with the palisade parenchyma, in the adaxial side. Numerous chloroplasts were observed (figure 6). 

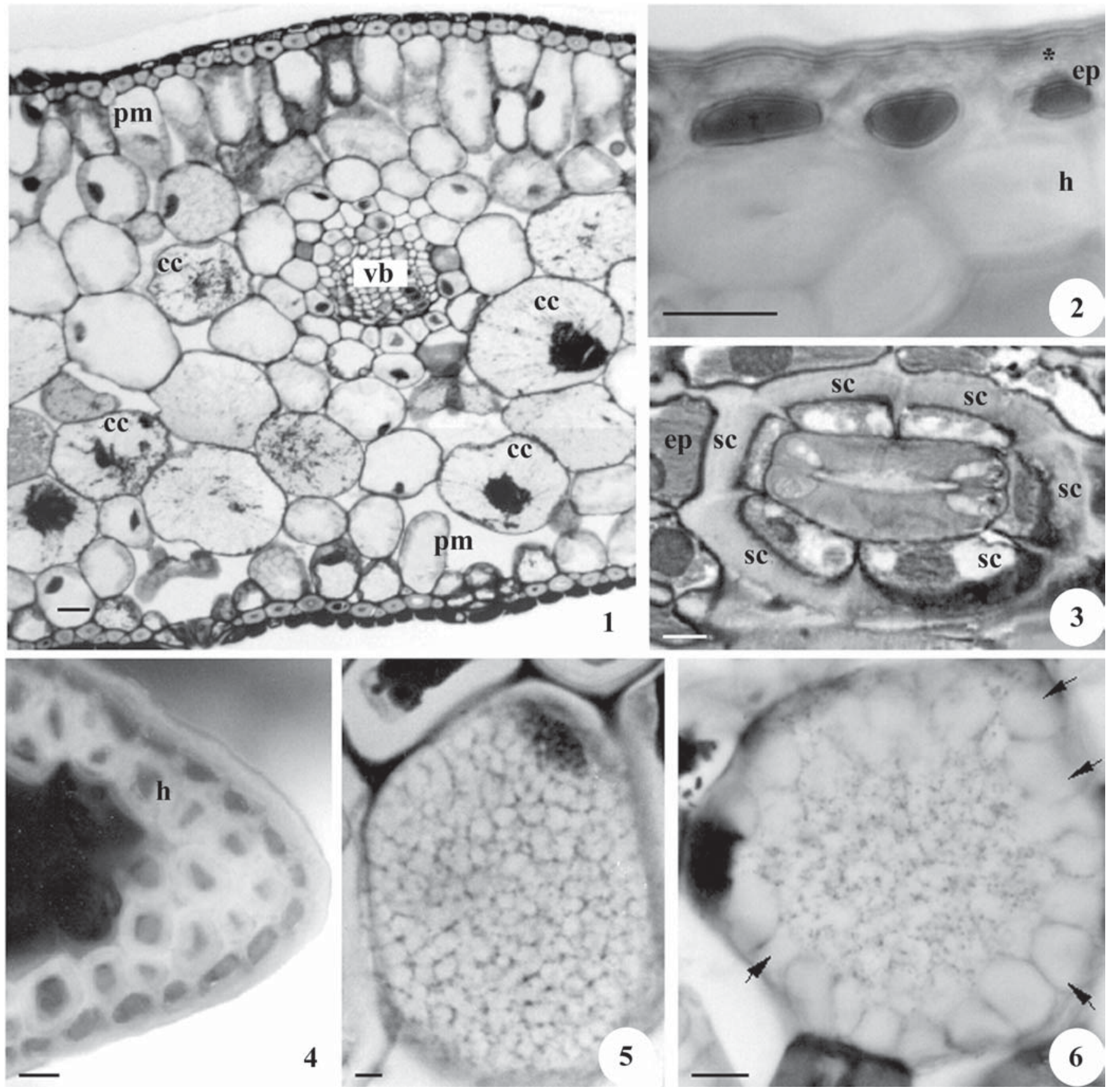

Figures 1-6. Mature leaves of the juvenile plant. 1. Transverse section of the mature leaf of juvenile plant. 2. Transverse section of fresh material of the leaf. Detail of the epidermis and outer periclinal cell wall (asterisk). Hypodermal cells presenting a second discontinuous layer. 3. Paradermal section of the epidermis, presenting a stoma with six subsidiary cells. 4. Transverse section of fresh material of the leaf. Detail of the leaf margin, presenting hypodermis with three layers. 5. Compartmented cell presents net-like pectic secretion in cell lumen. 6. Compartmented cell presenting pectinaceous mass and parietal chloroplasts (arrows). $\mathrm{cc}=$ compartmented cell, $\mathrm{ep}=$ epidermal cells, $\mathrm{h}=$ hypodermal cells, $\mathrm{pm}=$ palisade parenchyma, $\mathrm{sc}=$ subsidiary cells, $\mathrm{vb}=$ vascular bundle. $\mathrm{Bar}=10 \mu \mathrm{m}$. 
The resin canals are intercalated between the vascular bundles. However, it was observed many times the presence of a secretory canal under the central vascular bundle. The canals are limited by two cells layers, being the most outer one constituted of larger cells, with many phenolic compounds; and the most internal one is constituted by smaller cells, with thinner walls, forming the secretory epithelium.

There are four to six vascular bundles per leaf, enveloped by the transfusion tissue and by an endodermis. The endodermis is scarcely evident and is constituted by polygonal cells, in transverse section, slightly prolonged in paradermal section; sometimes with tannin in cell lumen. The transfusion tissue envelops the whole vascular bundle; being formed by transfusion tracheids and parenchyma cells (figure 7). The transfusion tracheids are shorter cells compared to the xylem tracheids in paradermal section, present bordered pits with torus in their walls, and are distributed laterally to the xylem (figure 8). The number of these cells may vary among four to six. The transfusion parenchyma is distributed adaxial and abaxially to the vascular bundle (figure 7). Parenchyma cells are intercalated with the lines of conduction elements.

One or two cell layers with thickened walls are identified, constituting a cap of crushed sieve cells of the protophloem (figure 7).

Anatomy of the mature leaves in adult plants - The cell types, present in the mesophyll of adult plants, differ from juvenile plants only due to the differentiation degree reached by the different tissues.

In adaxial side, two or three strata of prolonged cells constitute the palisade parenchyma (figure 9), but in abaxial side, there are one or two strata of this cells (not shown).

The spongy parenchyma is restricted to no more than one third of the mesophyll volume, presenting a very reduced number of compartmented cells (figure 9). In maturity, the compartmented cells presents the pectic secretion, better defined like lamellae (figure 10). The chloroplasts are absents. There are the differentiation of about six to seven layers of crushed sieve cells with very thickened and compressed walls (figure 11).

The transfusion tissue is constituted by a larger number of transfusion tracheids cells and associated parenchyma cells (figure 11).

Anatomy of the immature leaves of juvenile and adult plants - The epidermal cells have large dimensions and a polygonal shape, with very thick outer periclinal walls observed in optical microscopy (figures 12, 13). The mesophyll is not differentiated, being possible to identify the hypodermis with thin walls and many times the initiate of secondary walls development; vascular bundles; resin canals; and compartmented cells in great number, predominantly located in the abaxial side (figure 12). It was observed many times the presence of a secretory canal under the central vascular bundle (figure 12). The compartmented cells present a secretion not well-defined like "compartments".

Polarized light - Immature leaves. Under the polarized light analysis, the epidermis outer periclinal walls, the xylem tracheids, and phloem cells showed a strongly positive anisotropic reaction under polarized light. In contrast, the hypodermis and other mesophyll cells showed to be slightly polarized. The compartmented cells did not show birefringence in their compartments system (figure 14).

Mature leaves. The epidermis outer periclinal walls, the hypodermis, the transfusion tracheids, the transfusion parenchyma, the xylem tracheids, and the crushed cells below the phloem, showed to be more birefringent, when compared with the endodermis, the palisade and spongy parenchyma walls. The compartmented cells, as in the immature leaves, did not show birefringence in their compartments system (figures 15, 16).

Histochemical tests - They were performed to detail the anatomical characteristics, comparing immature and mature leaves of the juvenile plants.

Immature leaves (table 1) - The PAS test demonstrated that total polysaccharides ocurr in all cell wall of the analysed tissues, staining the compartmented cells secretion too (compartmented system) and the chloroplasts of spongy and palisade cells (not shown). The ruthenium red (pectins) and lugol (starch) tests detailed the PAS one. It was observed starch ocurrence only in chloroplasts. The pectins are present in the cell wall and nuclei of all analysed tissues, and in compartmented cells secretion. The observed tissues did not reacted with phloroglucinol $+\mathrm{HCl}$ (only guard cells, not shown in table). Lipid compounds were present in epidermis outer periclinal wall, showed by the orange and red staining with Steimetz and Sudan III tests, respectively.

Mature leaves of juvenile plants (table 2) - Beyond the cell wall, the compartmented cells secretion and nuclei reacted with ruthenium red. The lugol test demonstrated the presence of starch in chloroplasts. The PAS indicated the presence of polysaccharides already observed by ruthenium red and lugol. Phenolics compounds were present in hypodermis cells, palisade cells lumen, transfusion tracheids and xylem tracheids 

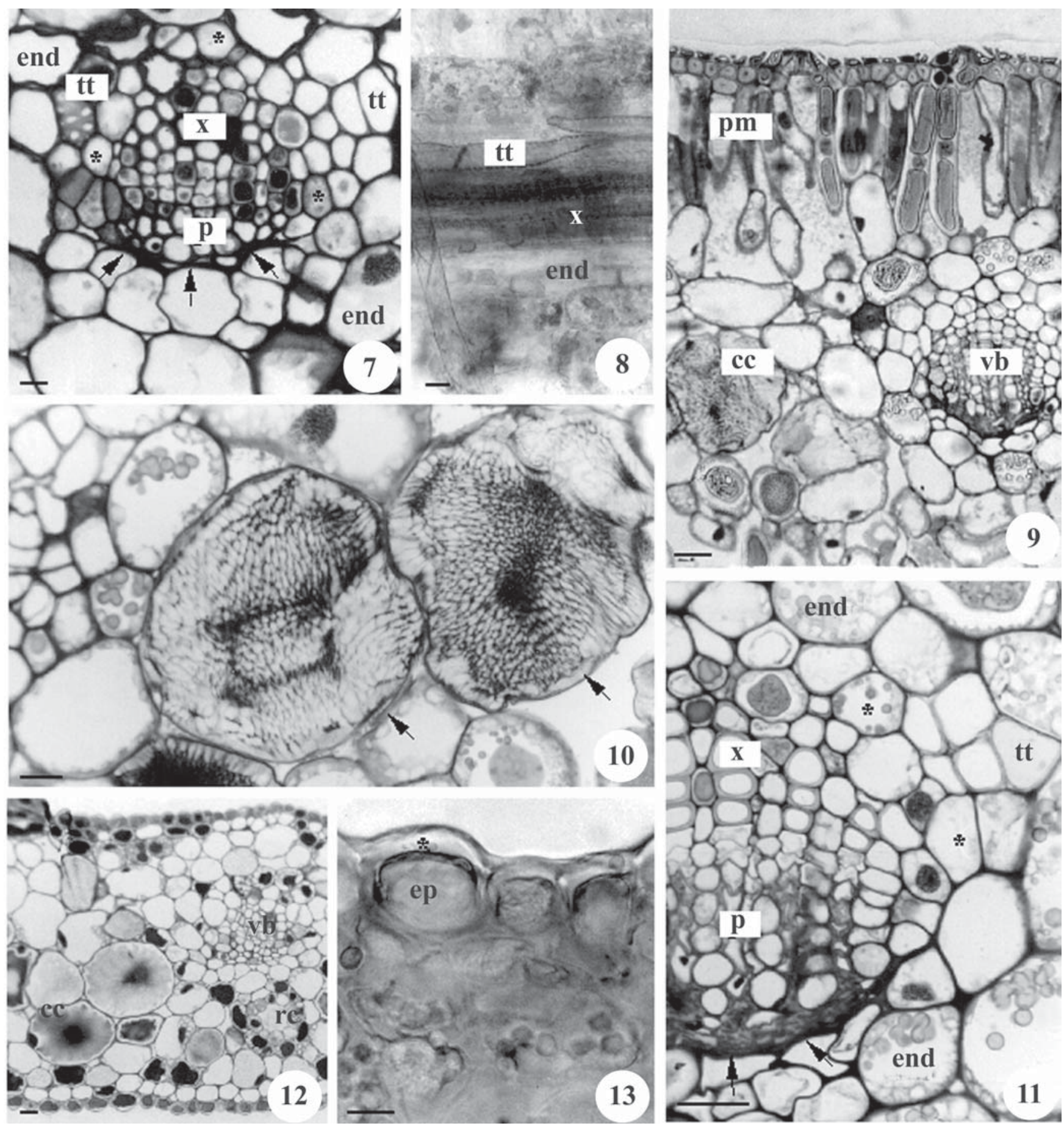

Figures 7-8. Mature leaf of the juvenile plant. 7. Transverse section of the vascular bundle. 8. Paradermal section of the vascular bundle. on lateral sides to the xylem. Figures 9-11. Mature leaf of the adult plant. 9. Transverse section of the mature leaf. 10. Compartmented cells (arrows) presenting a well-defined pectic lamellae in the cell lumen. 11. Detail of the vascular bundle in transverse section, presenting transfusion tracheids, transfusion parenchyma (asterisk) and a cap of crushed phloem (arrows). Figures 12-13. Immature leaves of the juvenile plant. 12. Transverse section of the leaf. 13. Transverse section of the fresh material, presenting detail of the epidermis and outer periclinal cell wall (asterisk). $c c=$ compartmented cell, ep $=$ epidermal cells, end $=$ endodermis, $\mathrm{p}=$ phloem, $\mathrm{rc}=$ resin canal, $\mathrm{pm}=$ palisade parenchyma, $\mathrm{tt}=$ transfusion tracheids, $\mathrm{vb}=$ vascular bundle $\mathrm{x}=$ xylem. Bar $=10 \mu \mathrm{m}$. 


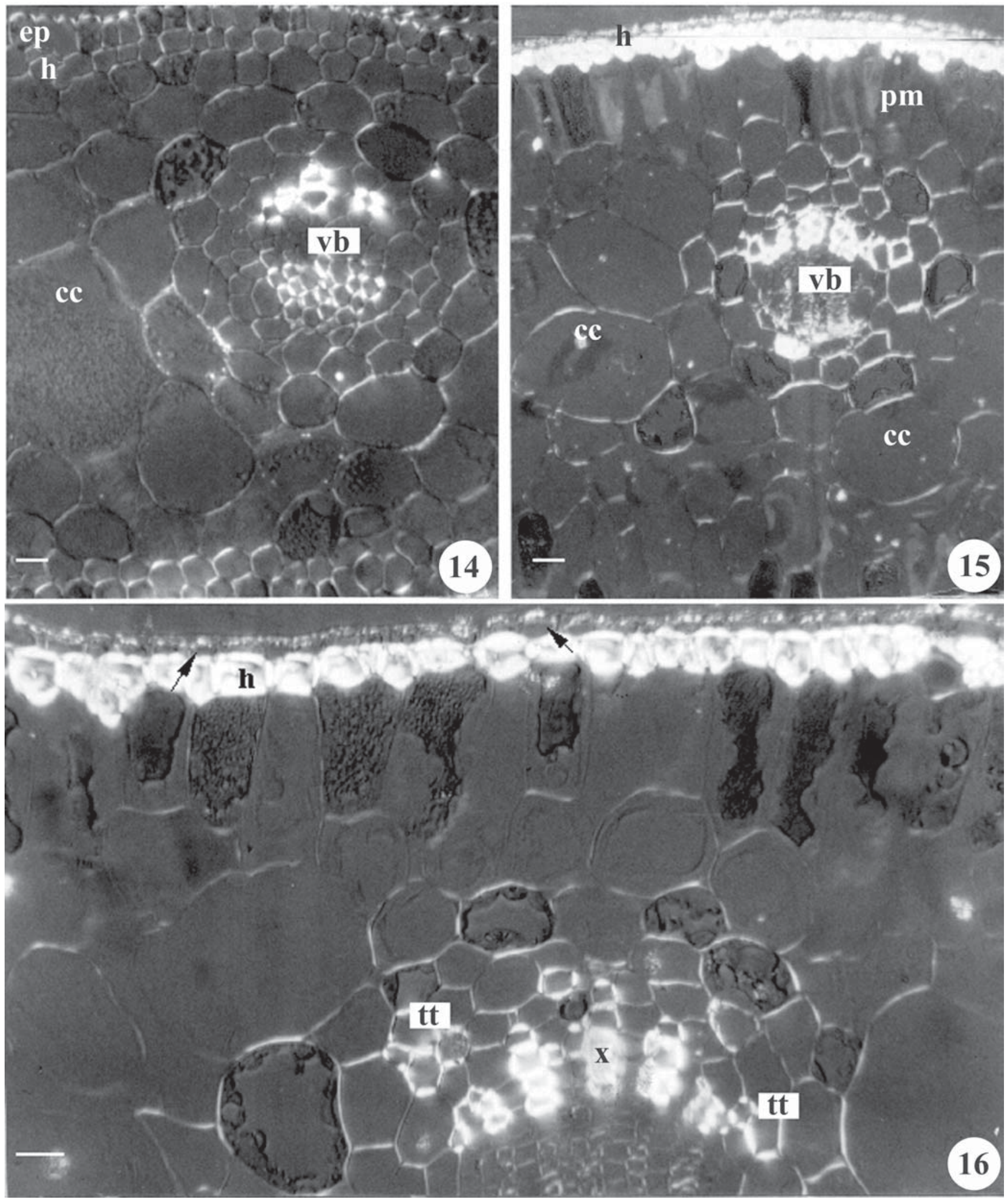

Figures 14-16. Immature and mature leaves of the juvenile plant under crossed polarizers. 13. Transverse section of the immature leaf. 14. Transverse section of the mature leaf. 15. Polarization of the epidermal outer periclinal wall (arrows), hypodermis, transfusion tracheids and xylem tracheids. $c c=$ compartmented cell, ep $=$ epidermis, $h=$ hypodermis, $p m=$ palisade parenchyma, $\mathrm{tt}=$ transfusion tracheids, $\mathrm{x}=$ xylem tracheids, $\mathrm{vb}=$ vascular bundle. $\mathrm{Bar}=10 \mu \mathrm{m}$. 
Table 1. Histochemical tests in different tissues of the immature leaves (+: presence; -: absent).

\begin{tabular}{|c|c|c|c|c|c|c|}
\hline Tissues & PAS & Ruthenium red & Lugol & $\begin{array}{l}\text { Phloroglucinol } \\
+\mathrm{HCl}\end{array}$ & Steimetz & Sudan III \\
\hline Cuticle & - & - & - & - & + & + \\
\hline $\begin{array}{l}\text { Epidermis outer } \\
\text { periclinal wall }\end{array}$ & + & + & - & - & + & + \\
\hline $\begin{array}{l}\text { Hypodermal cells } \\
\text { (cell wall) }\end{array}$ & + & + & - & - & - & - \\
\hline Compartmented cells & $\begin{array}{c}+ \\
\text { cell wall; } \\
\text { nucleus; } \\
\text { choroplasts; } \\
\text { secretion }\end{array}$ & $\begin{array}{c}\quad+ \\
\text { cell wall; } \\
\text { nucleus; } \\
\text { secretion }\end{array}$ & $\stackrel{+}{+}$ & - & - & - \\
\hline $\begin{array}{l}\text { Transfusion tracheids } \\
\text { (cell wall) }\end{array}$ & + & + & - & - & - & - \\
\hline Spongy cells & $\begin{array}{c}+ \\
\text { cell wall; } \\
\text { nucleus; } \\
\text { chloroplasts }\end{array}$ & $\begin{array}{c}+ \\
\text { cell wall; } \\
\text { nucleus }\end{array}$ & $\stackrel{+}{+}$ & - & $\begin{array}{c}+ \\
\text { choroplasts }\end{array}$ & - \\
\hline
\end{tabular}

(not shown) by the gold yellow staining with Steimetz test. The phloroglucinol $+\mathrm{HCl}$ test (lignins) allowed to demonstrate a stronger reaction intensity in the hypodermis cells of the abaxial leaf side. The lignins were presents in transfusion tracheids and xylem tracheids too (not shown), according the phloroglucinol $+\mathrm{HCl}$ test. This later and Sudan III also indicated the presence of lipids compounds in epidermis outer periclinal wall and cuticle by the orange staining.

\section{Discussion}

The differences observed between the immature and mature leaves of juvenile and adult plants, were characterized mainly by the development of the hypodermis and palisade parenchyma, number of compartmented cells, number of thickened and compressed cells under the phloem, and the development degree of the transfusion tissue.

It was observed that the epidermis is totally differentiated, probably in previous stages to the analyzed ones. In the mature leaves of juvenile and adults plants, Vasiliyeva (1969) described this tissue as constituted by cells with non-lignified thick walls, demonstrated by the lack of reaction to phloroglucinol test in this paper. Stockey \& Ko (1986) in several studies on the cuticular aspects of the genus Araucaria, characterized the leaf as having a thick cuticle, with intercellular flanges in the epidermal cells. However, it is suggested that the cuticle in A. angustifolia is very thin, as it was observed by Vasiliyeva (1969) and verified through the ruthenium red which demonstrated several deposits of middle lamella, in the outer periclinal wall, under the cuticle. Besides, such walls showed a high birefringence degree, demonstrating cellulose crystalinity, indicating the presence of a thick epidermal wall for both, immature and mature leaves. The positive results with Sudan III, also indicated the presence of lipid deposits in the outer periclinal and anticlinal walls of epidermal cells, for immature and mature leaves, many times confused with the cuticular flanges already discussed. Another characteristic is that the walls of the guard cells in the stomata of immature and mature leaves, when stained with phloroglucinol, showed to be very lignified (not shown). It can be inferred that this characteristic would also be related to the water loss control, because the lignin could be related to guard cells resistence when they are turgids. This characteristics are typical for xerophytes (Esau 1965) and the ocurrence in juvenile plants demonstrate a premature protection to dry conditions. The ocurrence of guard cells at the same level of the epidermis, contradicts the xeromorphic characteristics already described to many conifers, which had been shown distributed in cavities (Kausik \& Battacharya 1977).

The mature leaves of juvenile plants showed that the epidermal tissue and the hypodermis are totally differentiated, like observed in adult ones. It is inferred 
Table 2. Histochemical tests in different tissues of the mature leaves (+: intense; ++ very intense; -: absent).

\begin{tabular}{|c|c|c|c|c|c|c|}
\hline Tissues & PAS & Ruthenium red & Lugol & $\begin{array}{l}\text { Phloroglucinol } \\
+\mathrm{HCl}\end{array}$ & Steimetz & Sudan III \\
\hline Cuticle & - & - & - & - & + & + \\
\hline $\begin{array}{l}\text { Epidermis outer } \\
\text { periclinal wall }\end{array}$ & + & + & - & - & + & + \\
\hline $\begin{array}{l}\text { Hypodermal cells } \\
\text { adaxial (cell wall) }\end{array}$ & + & + & - & + & + & - \\
\hline $\begin{array}{l}\text { Hypodermal cells } \\
\text { abaxial (cell wall) }\end{array}$ & + & + & - & H & + & - \\
\hline Compartmented cells & $\begin{array}{c}+ \\
\text { (?)chloroplasts; } \\
\text { cell wall; } \\
\text { secretion }\end{array}$ & $\begin{array}{c}+ \\
\text { cell wall; } \\
\text { secretion }\end{array}$ & $\begin{array}{c}+ \\
\text { chloroplasts }\end{array}$ & - & - & - \\
\hline $\begin{array}{l}\text { Transfusion tracheids } \\
\text { (cell wall) }\end{array}$ & + & + & - & + & + & - \\
\hline Palisade cells & $\begin{array}{c}+ \\
\text { cell wall } \\
\text { nucleus } \\
\text { chloroplasts }\end{array}$ & $\begin{array}{c}+ \\
\text { cell wall } \\
\text { nucleus }\end{array}$ & $\stackrel{+}{+}$ & - & $\begin{array}{c}+ \\
\text { lumen }\end{array}$ & - \\
\hline Spongy cells & $\begin{array}{c}+ \\
\text { cell wall; } \\
\text { nucleus } \\
\text { chloroplasts }\end{array}$ & $\begin{array}{c}+ \\
\text { cell wall; } \\
\text { nucleus }\end{array}$ & $\begin{array}{c}+ \\
\text { chloroplasts }\end{array}$ & - & $\stackrel{+}{+}$ & - \\
\hline
\end{tabular}

that these tissues would soon perform to protection function against mechanical damages and water loss, the vital characteristics during the first development months of young offspring.

It was observed that the lignin deposition is first verified in the abaxial side of the juvenile plants mature leaves. The reason and function of this intense deposition on the abaxial side is still unknown. Monteiro et al. (1977), observed the formation of four to five layers of hypodermal lignified cells in the leaf margin, while in the analyzed material, in immature and mature leaves, no more than three layers of this tissue were observed, as Barsali (1909) had already described.

In the immature leaves the palisade parenchyma is not differentiated yet. In the mature leaves of juvenile plants, this tissue is less developed, when compared to adult individuals. According to Monteiro et al. (1977), when analyzing one years-old Araucaria angustifolia plants, they observed that the palisade parenchyma would be present only in a simple layer on the adaxial side. These results conflicted with the material in study, where the mature leaves of juvenile plants of four mont age, already had a palisade parenchyma, also in the abaxial side, although less developed in relation to the adaxial one. In the adult plants, we observed the existence of this tissue in both sides already described for Araucaria and Podocarpus by Esau (1965) and with phenolic compounds in cell lumina. Barsali (1909) denominated this palisade tissue, less developed in the abaxial side, as pseudo-palisade, once the cells presented an ovoid-conical shape, differing from the palisade shape of the adaxial side. These observations seem to be characteristic of juvenile plants, although in his work, the age of the analyzed material has not been specified.

The number of compartmented cells among the mature and immature leaves of juvenile plants were similar, being observed a decrease in the adult plant mature leaves. Only Barsali (1909), Vasiliyeva (1969), Monteiro et al. (1977) and Bamber et al. (1978), described and/or mentioned the presence of the compartmented cells in the spongy parenchyma, differentiating them from the cells of this tissue and, even, characterizing them as another tissue, like Monteiro et al. (1977). However, Bamber et al. (1978) called them "compartmented cells" because these cells presents a system of partitions forming numerous "compartments" within the cell. The term "compartments" could be not appropriate, suggesting to be just a pectic secretion or pectic lamellae. The presence of pectic compounds had already been described by Bamber et al. (1978) and confirmed in this study by the ruthenium red. This kind of cells were 
also observed in the genus Wollemia of this family (Burrows \& Bullock 1999).

In the mature leaves of adult plants the transfusion tissue had showed an increase in number of transfusion tracheids. This kind of tissue is probably originated from pericycle cells present in the internal side of endodermis, surrounding the vascular bundles of immature leaves. These cells, after successive divisions, are induced to differentiate, due to topographic matters, in transfusion tracheids, located beside the xylem. In general, the pericycle is described like parenchyma cells or "phloem fibers", but Altamura et al. (1998), observing the development of a sheath surrounding phloem and xylem in tobacco leaf explants, cultured in vitro, relationed them like pericycle cells. Besides, it also happens the maintenance of differentiated parenchyma cells around the vascular bundle.

The aliform distribution of transfusion tracheids on the xylem, is in agreement with the proposal made by $\mathrm{Hu} \&$ Yao (1981), who classified it as being of the Araucaria type, being found in Agathis, Araucaria and Podocarpus imbricatus. These authors do not consider the distribution of the transfusion parenchyma which occurs both in the adaxial side and in the abaxial side of the vascular bundle, as Kausik \& Battacharya (1977) compare, in opposition to Esau (1965) who describes its occurrence only in the abaxial side of the bundle.

According to several authors (Ghouse 1973, Ghouse \& Yunus 1975, Kausik 1976, Kausik \& Battacharya 1977, Hu \& Yao 1981) the transfusion tissue is composed by three kinds of cells: transfusion tracheids, parenchyma cells and albuminous cells. However, the descriptions made by these authors to the albuminous cells seem to be wrong, once they point them as located adjacent to the phloem, confined to the base of the transfusion tracheids archs. In fact, the albuminous cells constituted part of the phloem, having its origin in the axial and radial system and with a function similar to the companion cells of the sieve elements of the angiosperms (Esau 1969). The observations made in the Araucaria angustifolia seem to be in agreement with Esau (1965), who suggested only the existence of transfusion tracheids and parenchyma cells in the transfusion tissue.

Considering the transfusion tracheids of the analysed Araucaria angustifolia, the wall differentiation result in bordered pits with torus. However, Esau (1965) described that the transfusion tracheids possesses lignified walls and bordered pits. In the specialized literature it was also discussed the occurrence of spiral thickeness, in the Araucaria type, according to $\mathrm{Hu} \&$ Yao (1981). This kind of wall thickeness was not observed in the analysed material.

In spite of the endodermis had not shown the usual characteristics observed in Pinaceae (Esau 1965, Mauseth 1988, Fahn 1990), its topographic position allowed to identify it, in a precise way, in Araucaria angustifolia.

Finally, the reduced number of leaf resin canals has already been mentioned by Monteiro et al. (1977), as well as its distribution intercalated with the vascular bundles mentioned by Barsali (1909), Vasiliyeva (1969) and Suzuki (1979). However, the occurrence of a resin canal under the vascular bundle, as it was reported in this paper, had not been suggested yet, been a new record to the knowledge of Araucaria.

Most of the leaves anatomical characteristics, in juvenile and adult plants confirmed the previous observations accomplished to the genus Araucaria. However, some structures like the epidermis outer periclinal walls, albuminous cells, phloem and transfusion tissue (originated from pericycle), would deserve a better detailing, having in mind conflicts among different authors.

The results are clear in relation to anatomical differences between juvenile and adult plants (mature leaves), and these descriptions can be useful for recognize them at the forest.

From the biogeographical point of view, the Araucariaceae are one of the most interesting families with primarily Southern Hemisphere distribution. The family consists of three well-defined genera (Araucaria, Agathis and Wollemia), which Araucaria genus enclose 19 species sensu de Laubenfels (1988). Few features are available to separate Araucaria from Agathis and Wollemia. Apparently, the most definitive of these characters are the presence or absence of compartmented cells (absence in Agathis), followed by hypodermal fibres distribution (a continuous layer in Araucaria and Wollemia) and whether stomata are present on both leaf surfaces (most Agathis species are hypostomatic, but Araucaria and Wollemia species are amphistomatic). The leaf anatomy of Wollemia has greater similarity to Araucaria than to Agathis (Burrows \& Bullock 1999), however two molecular studies demonstrated that Wollemia has a closer relationship to Agathis than to Araucaria (Gilmore \& Hill 1997, Stefanovic et al. 1998). In contrast, Setoguchi et al. (1998) described that Wollemia derived first and then Agathis and Araucaria. 
Acknowledgements - To the Anatomy Laboratory, Botany Department, UFRGS, and to CNPq, for the financial assistance. To the administrator of the National Forest of São Francisco de Paula (RS), Artur Soligo, for the support and the collections permission. To the technician Bibiana Cassol for the support of technical doubts. To CNPq for Master degree grant-maintained to the first author and research support to the second one.

\section{References}

ALTAMURA, M.M., ZAGHI, D., SALVI, G., De LORENZO \& BELLINCAMPI, D. 1998. Oligogalacturonides stimulate pericycle cell wall thickening and cell divisions leading to stoma formation in tobacco leaf explants. Planta 204:429-436.

BACKES, A. 1999. Condicionamento climático e distribuição geográfica de Araucaria angustifolia (Bert.) O. Ktze. no Brasil-II. Pesquisas, Botânica 49:5-40.

BAMBER, R.K., SUMMERVILLE, R. \& GREGORY, J. 1978. Unusual cells in the mesophyll zone of leaves of Araucaria. Australian Journal of Botany 26:177-187.

BARSALI, E. 1909. Studio sul gen. Araucaria Juss. Atti Sociedad Toscana Science 25:145-184.

BURLINGAME, L.L. 1913. The morphology of Araucaria brasiliensis. I. The staminate cone and male gametophyte. Botanical Gazette 55:97-114.

BURLINGAME, L.L. 1914. The morphology of Araucaria brasiliensis. II. The ovulate cone and female gametophyte. Botanical Gazette 57:490-507.

BURLINGAME, L.L. 1915. The morphology of Araucaria brasiliensis. III. Fertilization, the embryo and the seed. Botanical Gazette 59:1-69.

BURROWS, G.E. 1987. Leaf axil anatomy in the Araucariaceae. Australian Journal of Botany 35:631-640.

BURROWS, G. \& BULLOCK, S. 1999. Leaf anatomy of Wollemi pine (Wollemia nobilis, Araucariaceae). Australian Journal of Botany 47:795-806.

CARR, S.G.M. \& CARR, D.J. 1977. Diagnostic anatomical characters of the leaves of three species of Agathis. Brunonia 1:103-115.

CHAMBERLAIN, C.J. 1935. Gymnosperms. Structure and evolution. Dover Publications Inc., New York.

DE LAUBENFELS, D.J. 1988. Araucariaceae. Flora Malesiana Series 10:419-442.

ESAU, K. 1965. Plant anatomy. $2^{\text {nd }}$ ed. John Wiley \& Sons, New York.

ESAU, K. 1969. The phloem. Gebrüder Borntraeger, Berlin.

FAHN, A. 1990. Plant anatomy. $4^{\text {th }}$ ed. Pergamon Press, Oxford.

FERREIRA, A.G. 1977. Araucaria angustifolia (Bert.) O. Ktze. Germinação da semente e desenvolvimento da plântula. Tese de doutorado, Universidade de São Paulo, São Paulo.
FERREIRA, A.G. 1985. Aspectos fisiológicos do pinheiro brasileiro - semente e planta jovem. In Anais do XXXVI Congresso Nacional de Botânica. Curitiba, v.1, p.97-100.

FERREIRA, A.G., DIETRICH, S.M.C. \& HANDRO, W. 1979. Changes in the metabolism of Araucaria angustifolia during the early phases of germination and growth. Revista Brasileira de Botânica 2:76-81.

FRANCO, E.T.H. \& FERREIRA, A.G. 1987. Germination and early development of Araucaria angustifolia. Acta Botanica Brasilica 2:32-46.

GABRIEL, B.L. 1982. Biological electron microscopy. Van Nostrand Reinhold Company, New York.

GHOUSE, A.K.M. 1973. Ocurrence of transfusion tissue in leaves of Sequoia sempervirens (D. Don) Endl. Israel Journal of Botany 22:236-238.

GHOUSE, A.K.M. \& YUNUS, M. 1975. Transfusion tissue in the leaves of Thuja orientalis L. Annals of Botany 39:225-227.

GILMORE, S. \& HILL, K.D. 1997. Relationships of the Wollemi Pine (Wollemia nobilis) and a molecular phylogeny of the Araucariaceae. Telopea 7:275-291.

GURGEL FILHO, O.A. 1959. Sobre o crescimento do pinheiro brasileiro. Revista Agrícola (Piracicaba) 32:79-82.

GRIFFITH, M.M. 1952. The structure and growth of the shoot apex in Araucaria. American Journal of Botany 39:253-263.

HU, YU-SHU \& YAO, BI-JUN. 1981. Transfusion tissue in gymnosperms leaves. Botanical Journal of the Linnean Society 83:263-272.

JOHANSEN, D.A. 1940. Plant microtechnique. McGraw-Hill, New York.

JONES, W.G., HILL, K.D. \& ALLEN, J.M. 1995. Wollemia nobilis, a new living australian genus and species in the Araucariaceae. Telopea 6:173-176.

KAUSIK, S.B. 1976. Contribution to foliar anatomy of Agathis dammara, with a discussion on the transfusion tissue and stomatal structure. Phytomorphology 26:263-273.

KAUSIK, S.B. \& BATTACHARYA, S.S. 1977. Comparative foliar anatomy of selected gymnosperms: leaf structure in relation to leaf form in coniferales and taxales. Phytomorphology 27:146-160.

LIMA, C. 1963. Elementos de Botânica. Guia para trabalhos práticos. Livraria Mineira, Belo Horizonte.

MARCHIORI, J.N.C. 1996. Dendrologia das Gimnospermas. Editora da Universidade Federal de Santa Maria, Santa Maria.

MATTOS, J.R. 1994. O pinheiro brasileiro. 2ª ed. Artes Gráficas Princesa, Lages, v.2.

MAUSETH, J.D. 1988. Plant Anatomy. The Benjamin/ Cummings Publishing Company, Menlo Park.

MONTEIRO, S.M., FERREIRA, A.G. \& FLORES, F.E.V. 1977. Anatomia da plântula de Araucaria angustifolia (Bert.) O. Ktze. (Nota prévia). In Anais do XXI Congresso Nacional de Botânica, Curitiba, p.393-399.

NAPP-ZINN, K. 1966. Anatomie des Blattes. I. Gymnospermen. Handbuch der Pflanzenanatomie VII. Gebrüder Borntraeger, Berlin. 
O'BRIEN, T.P. \& McCULLY, M.E. 1981. The study of plant structure principles and selected methods. Temacarphi Pty, Melbourne.

PURVIS, M.J., COLLIER, D.C. \& WALLS, D. 1964. Laboratory techniques in botany. Butterwoths, London.

REITZ, R. \& KLEIN, R. 1966. Araucariáceas. In Flora Ilustrada Catarinense (R. Reitz, ed.). Herbário Barbosa Rodrigues, Itajaí, p. 1-65.

SASS, J.E. 1951. Botanical microtechnique. Iowa State University Press, Ames.

SETOGUCHI, H., OSAWA, T.A., PINTAUD, J-C., JAFFRÉ, T. \& VEILLON, J-M. 1998. Phylogenetic relationships within Araucariaceae based on rbcL gene sequences. American Journal of Botany 85:1507-1516.

SEWARD, A.C. \& FORD, S.O. 1906. The Araucarieae, recent and extinct. Philosophical Transactions Royal Society London B 198:305-412.

SHIMOYA, C. 1962. Contribuição ao estudo do ciclo biológico de Araucaria angustifolia (Bert.) O. Ktze. Experimentiae 4:519-546.
STEFANOVIC, S., JAGER, M., DEUTSCH, J., BROUTIN, J. \& MASSELOT, M. 1998. Phylogenetic relationships of conifers inferred from partial 28S rRNA gene sequences. American Journal of Botany 85:688-697.

STOCKEY, R.A \& KO, H. 1986. Cuticle micromorphology of Araucaria de Jussieu. Botanical Gazette 147:508-548.

STOCKEY, R.A. \& TAYLOR, T.N. 1978. Cuticular features and epidermal patterns in the genus Araucaria de Jussieu. Botanical Gazette 139:490-498.

SUZUKI, M. 1979. The course of resin canals in the shoots of conifers. II. Araucariaceae, Cupressaceae and Taxodiaceae. Botanical Magazine 92:253-274.

THOMSON, R.B. 1914. On the comparative anatomy and affinities of the Araucarineae. Philosophical Transactions of the Royal Society of London B 204:1-50.

VASILIYEVA, G.V. 1969. A contribution to the comparative anatomy of leaves of the species of Araucaria Juss. Botanicheskii Zhurnal SSSR 54:448-459.

YAMASAKI, S. \& DILLEMBURG, L.R. 1999. Measurements of leaf relative water content in Araucaria angustifolia. Revista Brasileira de Fisiologia Vegetal 11:69-75. 